\title{
4 years between diagnosis and insulin therapy in a case of slow onset typ
}

diabetes mellitus

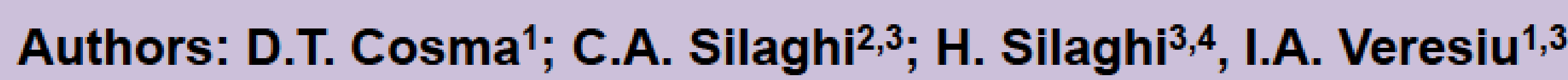

Coordinator: I.A. Veresiu

Diabetes, Nutrition and Metabolic diseases Clinical Center, Cluj-Napoca

${ }^{2}$ Endocrinology Clinic

3 "luliu Hatieganu" University of Medecine and Pharmacy, Cluj-Napoca

INTRODUCTION:

Type 1 diabetes mellitus (T1DM) is the most common form of diabetes in children and young adults. The natural history of type 1 diabetes involves $t$ following stages:

$\rightarrow$ a long preclinical period (antibodies and T-cells reactive with $\beta$-cell antigens can be detected)

$\rightarrow$ decline in $\beta$-cell function (observed years prior to the onset of clinical T1DM);

$\rightarrow$ hyperglycemic state ( $80-90 \%$ of the $\beta$-cells mass is lost due to insulitis in the presence of antibodies and T-cells directed against islet a

\section{CASE REPORT}

A 19-year-old male, diagnosed with T1DM at the age of 15, with no insulin treatment, was admitted to our department via a routine exam at his GP for high blood glucose (BG) values in the last 2 weeks (highest BG value of $365 \mathrm{mg} / \mathrm{dl}$ )

His past medical history was consistent with: left popliteal and left femural deep vein thrombosis in the context of a moderate $(27 \%)$ deficit of $S$ protein, mild dyslipidemia, moderate thinness $\left(B M I=21.8 \mathrm{~kg} / \mathrm{m}^{2} ; 50-75\right.$ percentile) and mild normocytic, normochromic anemia, for which he received treatment with Aspirin $75 \mathrm{mg}$ daily and iron. During hospitalization for thrombosis, he presented slightly elevated basal BG values, intermittent glycosuria but no ketonuria

\section{Labs exams:}

\begin{tabular}{|c|c|c|}
\hline July 2010 & December 2010 & March 2011 \\
\hline $\begin{array}{l}\text { basal BG=149 } \mathrm{mg} / \mathrm{dl} ; \\
2 \mathrm{~h}-\mathrm{OGTT}=386 \mathrm{mg} / \mathrm{dl} ; \\
\text { A1c=5.2\%; } \\
\text { GAD-Il=802 IE/ml (NV<10); } \\
\text { ICA Ab <1/10 (NV<1/10); } \\
\text { basal insulinemia=6.51 } \\
\text { ulU/ml (NV= 6-27); } \\
\text { C-peptide= } 1.52 \mathrm{ng} / \mathrm{ml} \\
(\mathrm{NV}=0.9-4)\end{array}$ & $\begin{array}{l}\text { basal BG=114 } \mathrm{mg} / \mathrm{dl} \text {; } \\
\text { A1c=5.2\%; } \\
\text { basal insulinemia }=7.7 \mathrm{ulU} / \mathrm{ml} \\
(\mathrm{NV}<27) ; \\
\text { C-peptide }=2.83 \mathrm{ng} / \mathrm{ml} \\
(\mathrm{NV}=0.9-4)\end{array}$ & $\begin{array}{l}\text { basal } B G=132 \mathrm{mg} / \mathrm{dl} \text {; } \\
\mathrm{A} 1 \mathrm{c}=7.28 \% \text {; }\end{array}$ \\
\hline
\end{tabular}

Table no. 1: Evolution of labs exams in the first months after diagnosis

\section{Type 1 DM (pro)}

- age;

- high level of GAD-II;

- C peptide and insulin levels in the normal lower range;

\section{MODY (cons) \\ - no family history for $\mathrm{DM}$; \\ - normal BG values of both parents:}

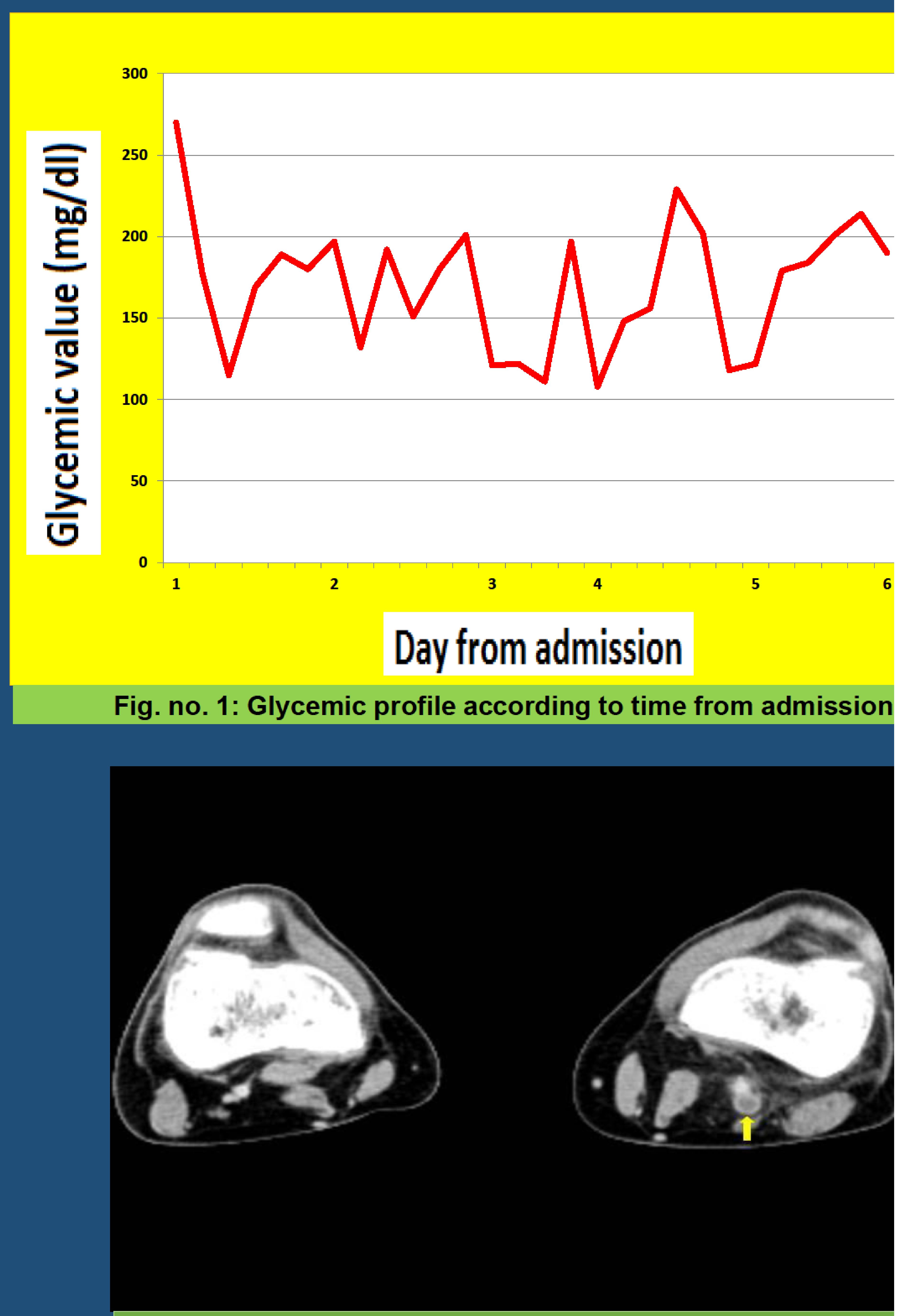

Fig. no. 2: Angio-CT (axial view): left popliteal vein thrombosis with edematous infiltrated adjacent fat

Table no. 2: Pro and cons for differential diagnosis

Due to good BG values under dietary treatment (with BG max $<170 \mathrm{mg} / \mathrm{dl}$ ), the insulin treatment was postponed. The patient had followed the dietary recommendations only 6 months.

At admission in our department: weight $=59 \mathrm{~kg} ; \mathrm{BMl}=16.7 \mathrm{~kg} / \mathrm{m}^{2}$; $\mathrm{BP}=105 / 75 \mathrm{mmHg}$; Pulse $=82 / \mathrm{min}$. Labs exams revealed: $\mathrm{G}=285 \mathrm{mg} / \mathrm{dl}$, mild hypokalemia, mild dyslipidemia, ketonuria $(150 \mathrm{mg} / \mathrm{dl})$, significant glycosuria $(1 \mathrm{~g} / \mathrm{dl})$ and the $\mathrm{A} 1 \mathrm{c}>14 \%$ was consistent with a sever glycemic imbalance in the last 3 months.

A basal bolus regimen with glargine and lispro insulin was started, adjusted according to the $B G$ values and carbs ingestion and respecting the correction factor (FC) of $1: 50 \mathrm{mg} / \mathrm{dl}$ and the sensibility factor (FS) of $1: 15 \mathrm{~g}$ carbs. The screening for diabetes-related microvascular complications and autoimmune diseases was negative.

\section{Discussions:}

The diagnosis of slow onset type $1 \mathrm{DM}$ :

$\rightarrow$ may be often a random discovery;

$\rightarrow$ involves mandatory the use of immunological labs exams and o sharp clinical judgment;

$\rightarrow$ may present a long asymptomatic period.

To our knowledge, this case presents the largest period (4 years) from the diagnosis of T1DM and initiation of the insulin therapy.

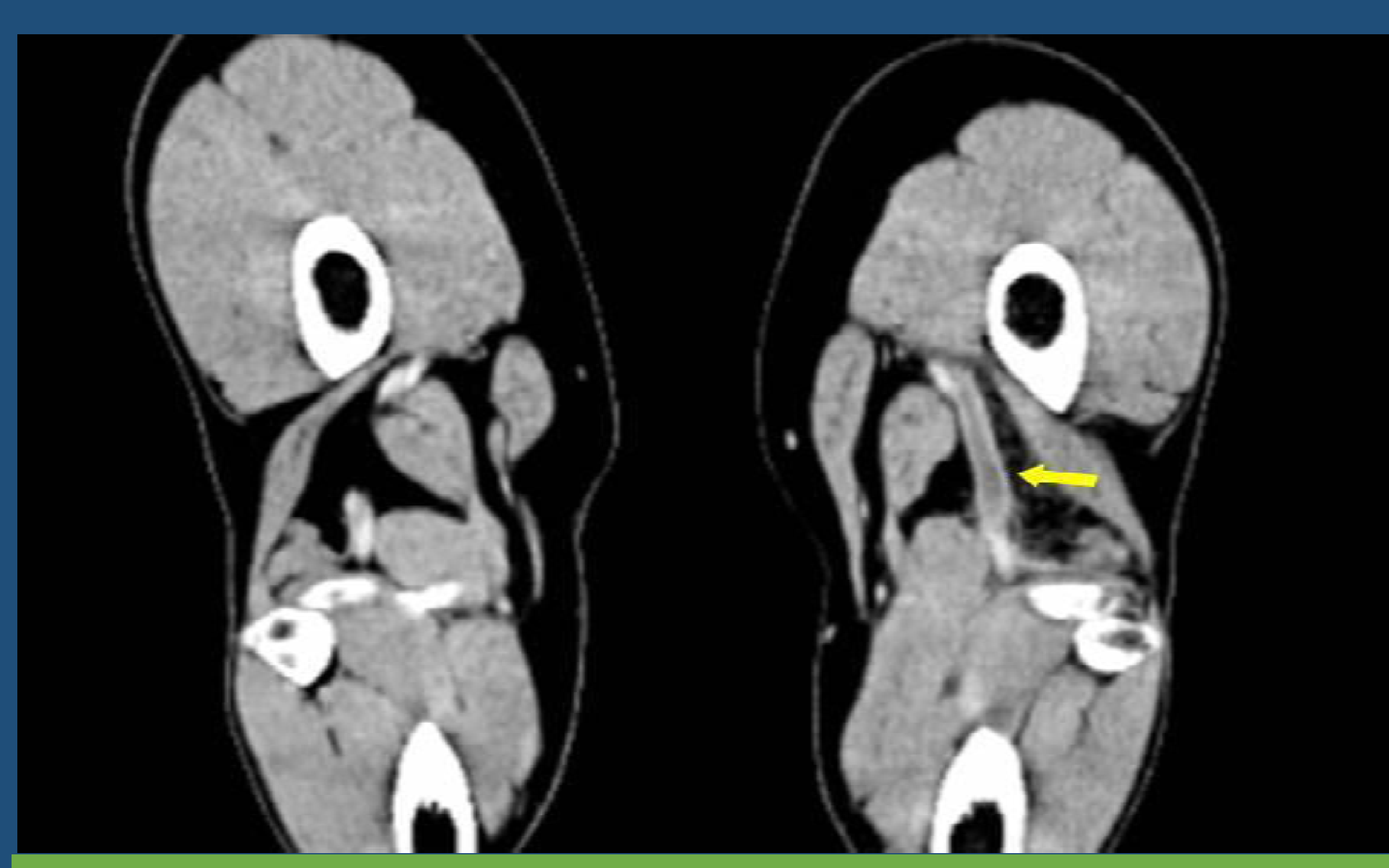

Fig. no. 3: Angio-CT (coronal section): left popliteal vein thrombosis edematous infiltrated adjacent fat 